\title{
顎口腔領域における多重癌症例の検討
}

\author{
水谷成孝・木下䩚彦・本間義郎・土肥雅彦 \\ 大塚亨・井上 聡・水沼秀之・志村介三
}

\section{Clinical study of multiple primary cancers in oral and maxillofacial regions}

\author{
Naritaka MizUTANi $\cdot$ Yukihiko Kinoshita $\cdot$ Yoshiro HonmA \\ Masahiko DohI • Tohru OHTUKA • Satoshi Inoue \\ Hideyuki Mizunuma • Kaizo Shimura
}

\begin{abstract}
This study reviewed 9 patients (2.8\%) with multiple primary oral cancer in the maxillofacial region who were treated at the Department of Oral and Maxillofacial Surgery of Kanagawa Dental College from 1970 to 1992 . The patients ranged from 36 to 73 years of age (mean 56 years). There were 3 males and 6 females. Primary cancers (all squamous cell carcinoma) were found in the mandibular and maxillary gingiva in 3 cases, right and left buccal mucosa in 1 case, right and left maxillary sinus in 1 case, tongue and buccal mucosa in 1 case, maxillary gingiva and buccal mucosa in 1 case, mandibular gingiva and buccal mucosa in 1 case, and in the mandibular gingiva and maxillary sinus in 1 case. Background factors included Plummer-Vinson syndrome in 1 case, and multiple leukoplakia in 3 cases. The interval between the appearance of primary and secondary carcinomas ranged from 6 months to 8 years and 5 months; the average interval was 3 years and 11 months. TNM classification of the primary cancer was $\mathrm{T} 1$ in 1 case, T2 in 5 cases, T3 in 3 cases, N0 in 4 cases, N1 in 5 cases, and M0 in every case. TNM classification of the secondary cancer was T1 in 3 cases, T2 in 3 cases, T3 in 3 cases, N0 in 6 cases, N1 in 3 cases, and M0 in every cases. TNM classification of the tertiary cancer was T1N0M0 in 2 cases. In primary carcinomas, 5 cases were treated with chemotherapy, radiation and surgery, 2 cases with chemotherapy and radiation, and 2 cases with surgery alone. In secondary lesions, 3 cases were treated with chemotherapy, radiation and surgery, 2 cases with radiation and surgery, 3 cases with surgery alone, and 1 case with chemotherapy and radiation. In tertiary lesions, 2 cases were treated with surgery alone. During an observation period ranging from 2 to 14 years. 5 patients are still alive and 4 have died of cancer.
\end{abstract}

Key words : multiple primary cancer (多重癌), oral and maxillofacial region (顎口腔領域)

\section{緒 言}

近年, 癌の治療成績向上や平均寿命の延長に伴って, 1 人の患者に複数の癌が認められることも, さほどま

神奈川歯科大学口腔外科学第 2 講座

（主任：志村介三教授）

Second Department of Oral and Maxillofacial Surgery, Kanagawa Dental College (Chief : Prof. Kaizo Shimura)

受付日：平成 5 年 10 月 28 日
れではなくなっている。顎口腔領域においても例外で はないが, しばしば第 2 癌, 第 3 癌の診断, 治療に苦 慮することがある。

今回, 神奈川歯科大学附属病院口腔外科にて, 過去 22 年間に経験した顎口腔領域内の多重癌症例につい て検討したので報告する。

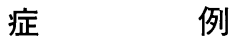

1970 年より 1992 年までの 22 年間に当科にて, 診 断，治療した顎口腔領域の悪性腫瘍は 312 例であり, 
表 1 当科における多重癌症例一覧

\begin{tabular}{|c|c|c|c|c|c|c|c|}
\hline 症例 No. & 年齢・性別 & 部＼cjkstart位 & 発生間隔 & $\mathrm{TN}$ 分類 & 治療法 & 背景因子 & 転帰 \\
\hline 1 & $\begin{array}{l}56 \text { 歳 } \\
\text { 女性 }\end{array}$ & $\begin{array}{l}\text { (1)右煩粘膜 } \\
\text { (2)左頓粘膜 }\end{array}$ & 1 年 6 加月 & $\begin{array}{ll}\text { T2 } & \text { N0 } \\
\text { T1 } & \text { N0 }\end{array}$ & $\begin{array}{l}\mathrm{C}, \mathrm{R} \\
\mathrm{C}, \mathrm{R}\end{array}$ & $\begin{array}{l}\text { Plummer- } \\
\text { Vinson Syn. }\end{array}$ & $\begin{array}{c}\text { 第 } 2 \text { 癌死 } \\
6 \text { 年 }\end{array}$ \\
\hline 2 & $\begin{array}{l}57 \text { 歳 } \\
\text { 女性 }\end{array}$ & $\begin{array}{l}\text { (1)右下顎歯肉 } \\
\text { (2)右上簤歯肉 }\end{array}$ & 4 年 & $\begin{array}{l}\text { T2 N0 } \\
\text { T2 N0 }\end{array}$ & $\begin{array}{l}\text { C, R, S } \\
C, R, S\end{array}$ & 特記事項なし & $\begin{array}{l}\text { 生存 } \\
14 \text { 年 }\end{array}$ \\
\hline 3 & $\begin{array}{l}36 \text { 歳 } \\
\text { 女性 }\end{array}$ & $\begin{array}{l}\text { (1)右上顎洞 } \\
\text { (2)左上頢洞 }\end{array}$ & 4 年 8 か月 & $\begin{array}{l}\text { T3 N1 } \\
\text { T3 N0 }\end{array}$ & $\begin{array}{l}\text { C, R, S } \\
\text { C, R, S }\end{array}$ & 特記事項なし & $\begin{array}{l}\text { 生存 } \\
13 \text { 年 }\end{array}$ \\
\hline 4 & $\begin{array}{l}47 \text { 歳 } \\
\text { 男性 }\end{array}$ & $\begin{array}{l}\text { (1)舌 } \\
\text { (2)煩粘膜 }\end{array}$ & 8 年 5 か月 & $\begin{array}{l}\text { T1 N0 } \\
\text { T3 N1 }\end{array}$ & $\begin{array}{l}\mathrm{C}, \mathrm{R} \\
\mathrm{R}, \mathrm{S}\end{array}$ & 飲酒・喫煙 & $\begin{array}{c}\text { 第 } 2 \text { 癌死 } \\
10 \text { 年 }\end{array}$ \\
\hline 5 & $\begin{array}{l}53 \text { 歳 } \\
\text { 男性 }\end{array}$ & $\begin{array}{l}\text { (1)左上顎歯肉 } \\
\text { (2)煩粘膜（上唇） }\end{array}$ & 1 年 5 か月 & $\begin{array}{ll}\text { T3 } & \text { 1 } \\
\text { T1 } & \text { N0 }\end{array}$ & $\begin{array}{l}\mathrm{C}, \mathrm{R}, \mathrm{S} \\
\mathrm{S}\end{array}$ & 多発性白板症 & $\begin{array}{l}\text { 生存 } \\
6 \text { 年 }\end{array}$ \\
\hline 6 & $\begin{array}{l}63 \text { 歳 } \\
\text { 女性 }\end{array}$ & $\begin{array}{l}\text { (1)右下顎歯肉 } \\
\text { (2)左下顎歯肉 } \\
\text { (3)右上靧歯肉 }\end{array}$ & $\begin{array}{c}4 \text { 年 } 2 \text { か月 } \\
7 \text { か月 }\end{array}$ & $\begin{array}{ll}\mathrm{T} 2 & \mathrm{~N} 0 \\
\mathrm{~T} 2 & \mathrm{~N} 1 \\
\mathrm{~T} 1 & \mathrm{~N} 0\end{array}$ & $\begin{array}{l}\mathrm{C}, \mathrm{R}, \mathrm{S} \\
\mathrm{C}, \mathrm{R}, \mathrm{S} \\
\quad \mathrm{S}\end{array}$ & 特記事項なし & $\begin{array}{l}\text { 生存 } \\
5 \text { 年 }\end{array}$ \\
\hline 7 & $\begin{array}{l}73 \text { 歳 } \\
\text { 女性 }\end{array}$ & $\begin{array}{l}\text { (1)左下顎歯肉 } \\
\text { (2)煩粘膜（下唇） }\end{array}$ & 6 か月 & $\begin{array}{ll}\text { T2 } & \mathrm{N} 1 \\
\mathrm{~T} 1 & \mathrm{~N} 0\end{array}$ & $\begin{array}{l}\mathrm{S} \\
\mathrm{S}\end{array}$ & 多発性白板症 & $\begin{array}{c}\text { 第 } 1 \text { 癌死 } \\
3 \text { 年 }\end{array}$ \\
\hline 8 & $\begin{array}{c}55 \text { 歳 } \\
\text { 男性 }\end{array}$ & $\begin{array}{l}\text { (1)左下顎歯肉 } \\
\text { (2)右上顎洞 }\end{array}$ & 6 年 5 か月 & $\begin{array}{l}\text { T3 N1 } \\
\text { T3 N0 }\end{array}$ & $\begin{array}{c}\mathrm{C}, \mathrm{R}, \mathrm{S} \\
\mathrm{R}, \mathrm{S}\end{array}$ & 飲酒・喫煙 & $\begin{array}{c}\text { 第 } 2 \text { 癌死 } \\
8 \text { 年 }\end{array}$ \\
\hline 9 & $\begin{array}{l}62 \text { 歳 } \\
\text { 女性 }\end{array}$ & $\begin{array}{l}\text { (1)右下顎歯肉 } \\
\text { (2)左下顎歯肉 } \\
\text { (3)右上䝷歯肉 }\end{array}$ & $\begin{array}{l}4 \text { 年 } 2 \text { か月 } \\
1 \text { 年 } 2 \text { か月 }\end{array}$ & $\begin{array}{ll}\text { T2 } & \mathrm{N} 1 \\
\mathrm{~T} 2 & \mathrm{~N} 1 \\
\mathrm{~T} 1 & \mathrm{~N} 0\end{array}$ & $\begin{array}{l}\mathrm{S} \\
\mathrm{S} \\
\mathrm{S}\end{array}$ & $\begin{array}{c}\text { 多発性白板症 } \\
\text { 喫煙 }\end{array}$ & $\begin{array}{c}\text { 生存 } \\
7 \text { 年 } 3 \text { 加 }\end{array}$ \\
\hline
\end{tabular}

このうち顎口腔領域内の多重癌は 9 例 $(2.8 \%)$ であっ た．臨床的事項の概要は表 1 のごとくである（表 1 ）. なお多重癌の診断は Warren and Gates ${ }^{1)}$ の基準に 従った。

\section{1。性ならびに年齢}

性別では男性 3 例，女性 6 例であり，初診時の年齢 は 36〜73 歳, 平均 56 歳であった。

\section{2．原発部位および臨床進展度}

発生部位の組み合わせは，下顎歯肉と上顎歯肉が 3 例（症例 $2,6,9$ ), 左右の煩粘膜（症例 1 ）（写真 $\mathbf{1} \mathbf{a}, \mathbf{b})$, 左右の上顎洞 (症例 3 ), (写真 $2 \mathbf{a}, \mathbf{b})$, 舌と煩粘膜（症例 4 ），上顎歯肉と煩粘膜（症例 5 ）, 下顎歯肉と煩粘膜（症例 7 ), 下顎歯肉と上顎洞 (症例 8 ）が各 1 例であった。第 1 癌の臨床進展度は $\mathrm{T} 1$ が 1 例, T2 が 5 例, T 3 が 3 例, N0 が 4 例, N 1 が 5 例で, 全例 M0 であった。 その臨床病期は Stage I が 1 例, Stage II が 4 例, Stage III が 4 例であった. 第 2 癌では $\mathrm{T} 1$ が 3 例， T2 が 3 例， T3 が 3 例で， N 0 が 6 例，N1 が 3 例で，全例 M0 であった。臨床病期 は Stage I が 3 例, Stage II が 1 例, Stage III が 5 例であった．第 3 癌の 2 例はいずれも T1N0M0, Stage Iであった.

\section{3，発生間隔}

第 1 癌と第 2 癌の発生間隔は, 最短 6 か月, 最長 8 年 5 か月, 平均 3 年 11 か月であった。 1 年以内に第 2 癌を生じたものは 1 例で， 9 例中 5 例は 4 年以上経過 後に第 2 癌が発見された。 また, 第 2 癌と第 3 癌の発 生間隔は 7 か月と. 1 年 2 か月であった.

\section{4. 病理組織学的所見}

組織型はすべて扁平上皮癌であった，第 1 癌と第 2 癌あるいは第 3 癌で分化度, 異型度などの組織学的悪 性度に差がなかったものは 4 例, 第 2 癌あるいは第 3 癌が第 1 癌に比べ組織悪性度の低いものが 3 例, 逆に 高いものが 1 例であった.

\section{5. 治療法}

第 1 癌に対しては, 手術単独が 2 例, 手術十化学療 法十放射線外照射が 5 例, $\mathrm{Ra}$ 針組織内照射+化学療 法が 2 例であった，第 2 癌に対しては，手術のみが 3 例, 手術+化学療法十放射線外照射が 3 例, 手術+放 射線外照射が 2 例，化学療法十放射線外照射が 1 例で あった。第 3 癌の 2 例に対しては，手術のみが行われ た.

\section{6. 背景因子}

背景因子としては Plummer-Vinson 症候群が 1 例 （症例 1 ), 多発性白板症が 3 例(症例 $5 ， 7 ， 9$ ), 飲 


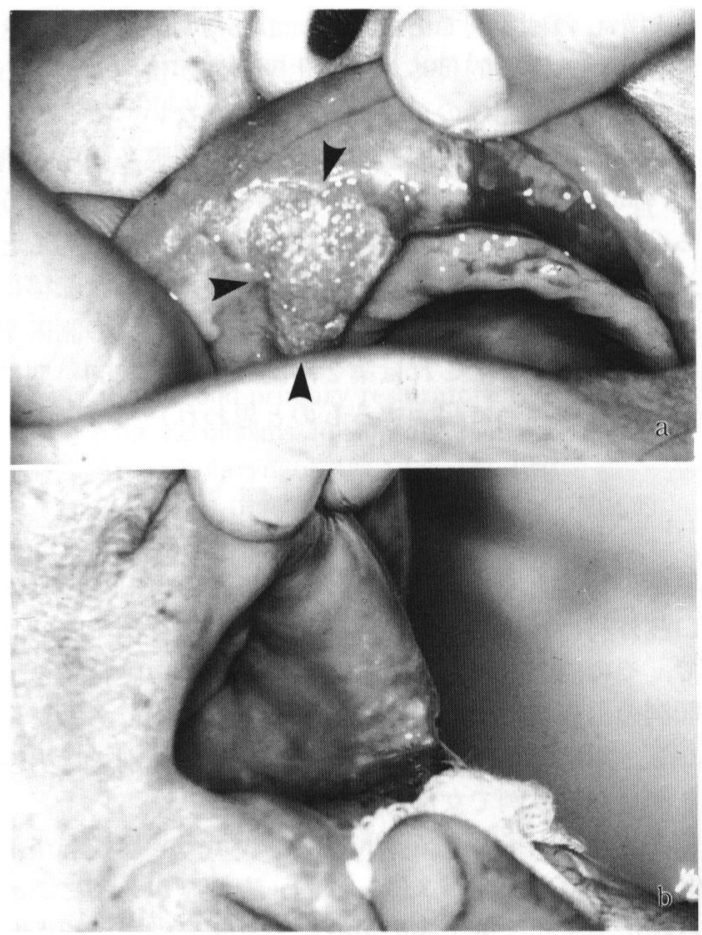

写真 1 症例 1 の口腔内写真 $\mathrm{a}$ ：第 1 癌 (矢印), b : 第 2 癌

酒十喫煙歴が 2 例 (症例 4，8)，契煙が 1 例 (症例 9) であったそその他の症例には，あきらかな背景因子は 認められなかった。

\section{7。転帰}

$2 \sim 14$ 年, 平均 8 年の観察期間では, 生存 5 例, 原 病死 4 例であった。原病死の内訳は第 1 癌の頸部転移 によるものが 1 例, 第 2 癌が制御できなかったものが 3 例であり, そのうち頸部転移, 原発巣, 肺転移によ るものが各 1 例であった。死亡例の平均生存期間は 6 年 7 か月であった.

\section{考察}

多重癌とは，1つの個体に複数発生した原発性癌と 定義されるが，このうち異なる 2 つ以上の蔵器（また は組織) に腫瘍が発生した場合は重複癌, 同一臓器 (ま たは組織）に複数の腫瘍が発生した場合は多発癌とさ れ, 両者を総称して多重癌と呼称されている我。多重 癌の判定基準の厳密さは報告者 ${ }^{1,2,4)}$ にって異なる が，現在では，Warren and Gates ${ }^{1)} の$ 基準，すなわち， 1. 各腫瘍は一定の悪性像を示す。2 . 各腫瘍は互い に離れた部位を占める。 3 。一方の腫瘍が他方の腫瘍 の転移であることが除外されなければならない，が広 く用いられている。

口腔領域では癌の組織型がほとんど扁平上皮癌であ
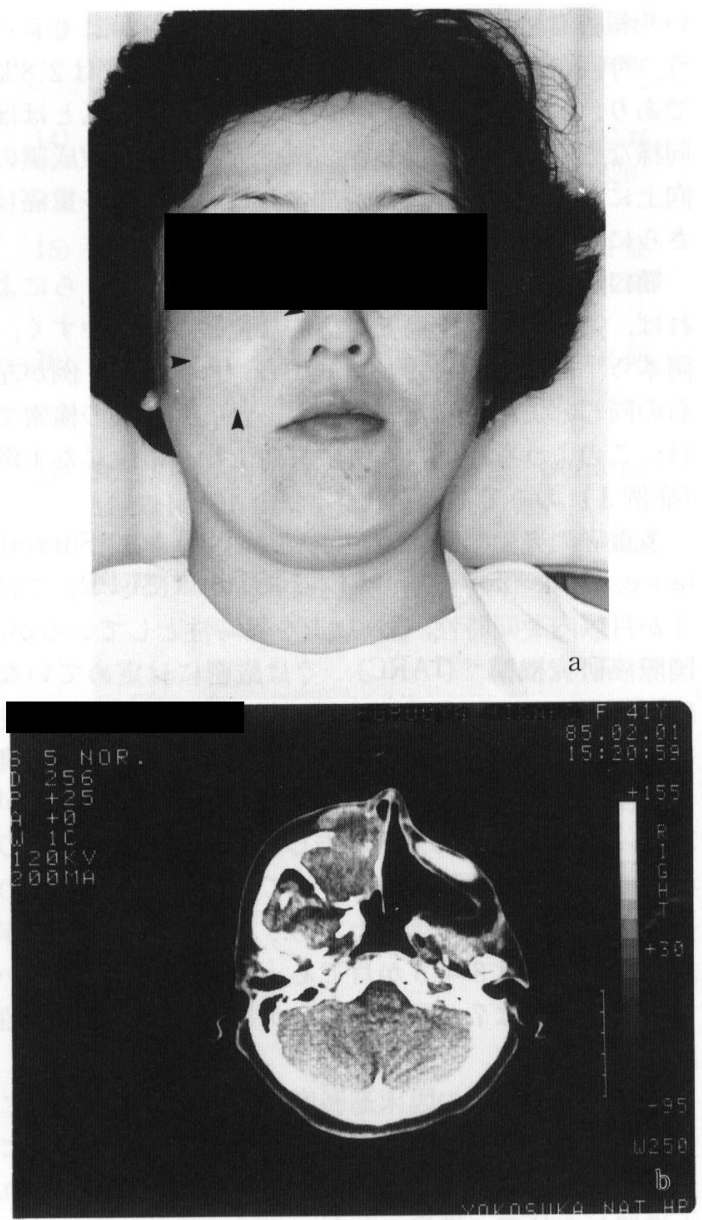

写真 2 症例 3 の病態写真

$\mathrm{a}$ : 第 1 癌 (顔正面), $\mathrm{b}$ : 第 2 癌（水平断 CT 撮影）

り，範囲も狭いことから，しばしば再発か多発癌かの 判断に因難をきたす。この点について, 上野ら 的に 2 つの腫瘍が $1.5 \mathrm{~cm}$ 以上離れていることを多発 癌の条件とし, また, 大矢ら ${ }^{6)}$ は各腫瘍間の独立性を組 織学的に厳密に検討すべきと述べている.

以上の点を考慮し，判断すると，今回の検索では， 症例 8 は口腔粘膜と上䫟洞との重複癌, 症例 3 は両側 上䕱洞の多発癌, 他の 7 例は口腔粘膜の多発癌と診断 できる。

多重癌の好発部位に関しては, 一般に消化器系, 特 に口腔と食道, 食道と胃, 胃と大腸のように消化管内 で上から下への関係があるといわれている7). 一方, 渡 辺ら ${ }^{8)}$ は第 1 癌が口腔癌の場合, 第 2 癌も口腔癌のこ とが多く，ついで食道癌，以下，喉頭癌，胃癌に多い と報告している。腔と他臓器との組み合わせを含め た多重癌の頻度は欧米では悪性腫瘍の $10 \%$ を越える との報告 ${ }^{9,10)}$ も みれているが, 本邦では $1.6 \sim 10.1 \%^{5,6,11,12)}$ と報告されている.これは人種の違 
いや報告者による診断精度，判定基準の違いにもよろ う。 今回の顎口腔領域に限った多重癌の頻度は $2.8 \%$ であり,これは岡本ら ${ }^{12}$ の口腔領域での $2.9 \%$ とほほ 同様な頻度であった。しかし，今後，癌の治療成績の 向上により長期生存例が増加するにつれて, 多重癌は さらに増加するものと思われる。

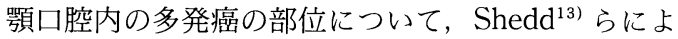
れば，第 2 癌は第 1 癌と対称的な位置に生じやすく, 岡本ら ${ }^{12)}$ は 11 例中 2 例が, 瀧田ら ${ }^{14)}$ は 4 例中 1 例が左 右の同じ部位に生じたと報告している.今回の検索で は，このような症例は 9 例中左右上顎洞に生じた 1 例 （症例 3 ）のみであった。

多重癌の発生間隔について米国 NCI の Surveillance, Epidemiology and End Results (SEER) では 2 か月以内を同時性, それ以上を異時性としているが, 国際癌研究機構 (IARC) では厳密には定めていな い3．実際には，1 年末満を同時性，それ以上を異時性 とする報告が多い ${ }^{15)}$ ，渡辺ら ${ }^{8}$ は口腔癌患者に第 2 癌 が発生するまでの期間は 1 年未満が $47 \%, 2 \sim 4$ 年が $31 \% ， 5 \sim 9$ 年が $10 \%$ と報告している. 今回の 9 例の 検索では，1例を除き他はすべて第 1 癌から第 2 癌の 発生までの期間は 1 年以上であり，その約半数は 4 年 以上で, 最長は 8 年 5 か月であった。 また, 第 2 癌か ら第 3 癌までは 7 か月と 1 年 2 か月であり, 比較的短 期間であった。

第 2 癌, 第 3 癌の臨床進展度は第 1 癌に比べ早期に 発見される傾向であったが, 第 2 癌が 8 年 5 か月後に 生じた症例 4 と, 上靧洞に生じた症例 3 では, いずれ も進展した状態で発見された。このことは口腔粘膜癌 におけるより長期の，かつ副鼻腔も含めた慎重な経過 観察の重要性を示していよう.

多重癌の背景因子としては, 1. 発癌物質への暴露, 2. 放射線, 3 . 癌化学療法, 4. 遺伝的素因, 5 . 免 疫能の低下， 6 。その他ホルモンなどの影響が考えら れている ${ }^{91}$. 兼松ら ${ }^{15}$ は，本邦における口腔多発癌 25 例中 5 例 $(20 \%)$ に白板症や乳頭腫様腫瘤などの粘膜 異常が， 9 例 $(36 \%$ ）に飲酒，喫煙，不適合義歯など の外因性要因がみられたと報告している．今回の症例 では, 1 例に Plummer-Vinson 症候群が，また 3 例 に白板症が認められた。 河原 ${ }^{16)}$ は口腔粘膜癌の周辺上 皮の臨床病理組織学的および核 DNA 量の検索結果か ら, これら周辺異常上皮に扔ける多発癌発生の可能性 を述べている．また顎口腔領域では喫煙と飲酒の影響 が疫学的にあきらかにされている ${ }^{17}$ が，今回の症例で は 3 例に飲酒, 喫煙歴がみられた。第 2 癌発生の予防 には, これら前癌病変や前癌状態への積極的な治療, 過度の飲酒，喫煙を避けることも重要である.

多重癌の発症と治療法との関係では，一般に第 1 癌 に放射線照射と化学療法が行われている場合が多 ${ }^{2)}$, 今回の症例では, 第 1 癌の照射野内に第 2 癌が発
生したものは 3 例であったが, このうち発生間隔が 8 年 5 か月と比較的長く, かつ化学療法が併用されてい る症例 4 は誘発癌の可能性も否定できない.

治療成績について, 福田ら ${ }^{18)}$ は口腔粘膜多発癌 6 例 中, 局所再発とリンパ節転移が各 5 例みられ，このう ち 2 例が死亡しており，第 2 癌の制御が困難であると 述べている. 今回の原病死 4 例のうち， 3 例は転移に よるもので, 原発巣死は 1 例であり, 原発巣の制御率 は良好であった。これは第 2 , 第 3 癌が比較的早期に 発見されたことに起因するものと思われた。

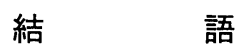

1. 1970 年より 1992 年までの間に神奈川歯科大学 口腔外科における顎口腔領域の多重癌は 9 例 $(2.8 \%)$ で, その内訳は口腔粘膜多発癌が 7 例, 口腔粘膜と上 顎洞の重複癌が 1 例, 両側上頡洞癌が 1 例であった。

2 . 年齢は $36 \sim 73$ 歳で, 平均 56 歳, 性別では男性 3 例, 女性 6 例で女性に多くみられた。

3. 背景因子として Plummer-Vinson 症候群が 1 例, 多発性白板症が 3 例, 飲酒, 喫煙歷が 3 例に認め られた。 また，第 1 癌の治療による誘発癌の可能性が 疑われたものは 1 例であった。

4 . 第 1 癌と第 2 癌の発症間隔は最短 6 か月, 最長 8 年 5 か月, 平均 3 年 11 か月であったが, 第 2 癌と第 3 癌の発症間隔は 7 か月と 1 年 2 か月であった。

5 . 2 年から 14 年の観察期間で生存は 5 例, 癌死は 4 例であった。

本論文の要旨は平成 2 年 5 月の第 44 回日本口腔科学 会総会（松江）に扔いて発表した。

\section{引用文 献}

1) Warren, S. and Gates, O. : Multiple primary malignant tumors, a survey of the literature and a statistical study. Am J Cancer 16 : 1358-1414 1932.

2) Moertel, C. G. : Multiple primary malignant neoplasms Historical perspectives. Cancer $40: 1786-17921977$.

3）渡辺 昌: 多重癌の実態と要因. 癌と化学療法 $17: 967-9731990$.

4）渡辺 昌：重複癌の病理．癌の臨床 $30 ： 1489-$ 14981984.

5）上野 正，清水正嗣：異時性多発口腔粘膜癌 7 症例について(抄)。日口外誌 $20: 712-713$ 1974.

6）大矢亮一, 池村邦男, 他：口腔多発癌および他 臟器との重複癌症例（抄）。口科誌 $35 ： 1125-$ 11261985.

7) Watanabe, S., Kodama, T., et al. : Second 
primary malignancies from patients with gastrointestinal cancers. Jpn J Clin Oncol 15 (Suppl. 1) : 171-182 1985.

8）渡辺昌, 小林友美子, 他：多重癌. 代謝 28： 271-277 1991.

9) Wangenfeld, D. J. H., Harwood, A. R., et al. : Second primary respiratory tract malignancies in glottic carcinoma. Cancer 46 : 1883-1886 1980.

10) Wangenfeld, D. J. H., Harwood, A. R., et al. : Second primary respiratory tract malignant neoplasms in supraglottic carcinoma. Arch Otolaryngol. 107 : 135-137 1981.

11）田代英雄：口腔粘膜癌発癌様相に関する臨床的 病理学的研究. 口科誌 $22: 176-1941973$.

12）岡本 学, 大関 悟, 他：口腔内多発癌症例の 検討. 日口外誌 36：389-399 1990 .
13) Shedd, D. P. and Kligerman, M. M. : Multi focal carcinogenesis in the oral cavity. Amer J Surg 104:692-696 1962.

14）瀧田正亮, 谷口文章, 他：頭頸部悪性腫瘍にお ける重複癌症例の検討。日口外誌 $36 ： 1320-$ 13261990.

15）兼松宣武, 安原 剛, 他：口腔内多発癌の 1 症 例ならびに文献的考察. 日口外誌 37：254-261 1991.

16）河原健司：口腔粘膜癌周辺異常上皮に関する研 究. 一臨床病理像と核 DNA 量による検討一. 神奈川歯学 27：30-42 1992.

17）渡辺昌：食道癌の成因と病態. Geriatric Medicine 27 : 1425-1429 1985.

18）福田雅幸, 松田耕策, 他：口腔粘膜多発癌 6 症 例の検討. 日口外誌 37：642-654 1991. 